reveal information about the movements of individuals because they focus on individuals and therefore do not support the model in which he is interested. Equally, his distinction between "successful" and "unsuccessful" migration rests purely on whether population change may have taken place. Curiously, Bellwood considers the Anglo-Saxon migrations into England successful but not the Norman invasion. Readers may well question whether Bellwood's "successful" migrations carried the same meaning in the past or whether such a notion of migration is an artefact of the way in which it is studied.

This becomes more evident in chapters 3 to 5 . Various episodes of the global spread of hominins during the Pleistocene are synthesized in an accessible way, taking into account much recent research, but can they be called migrations? The vast timescales imply incremental movements and make it impossible to compare meaningfully hominins moving out of Africa with the spread of agriculture or recent colonial conquests and migrations. Bellwood's global perspective also means that the impetus or local processes driving those movements are barely addressed.

Chapters 6 to 9 largely replicate Bellwood's earlier work, First Farmers (2005). The central thesis here is that domestication and food production resulted in an increase in population density, which required populations to expand and seek new areas to cultivate, taking their language and material culture with them. Renfrew's original study focused on the spread of proto-Indo-European out of its proposed homeland in Anatolia, in tandem with the spread of agriculture, and it is a subject still hotly debated (e.g., Anthony 2013; Bouckaert et al. 2012). Bellwood, however, goes further by using this as a model for the spread of language families globally, equally applicable to the spread of Bantu languages in sub-Saharan Africa and Andean languages.
The strength of First Migrants lies in its willingness to look at the big picture and an all-encompassing view of humanity, but this is also its weakness. Bellwood believes that his narrowly defined, large-scale population movements had significantly greater impact than other forms of migration. Yet, hunter-gather movements during the Palaeolithic, demic-diffusion as envisaged by Renfrew, and the AngloSaxon migrations are all quite different things, operating at different geographical and chronological scales. Rather than attempting a one-size-fits-all explanation, Bellwood might have strengthened his argument by examining the specific circumstances under which the model holds up as well as when it does not. Instead, the great variability of human migratory responses to social and environmental changes has fallen by the wayside.

\section{REFERENCES CITED}

Anthony, David W.

2013 Two IE Phylogenies, Three PIE Migrations, and Four Kinds of Steppe Pastoralism. Journal of Language Relationship 9:121.

Bellwood, Peter

2005 First Farmers: The Origins of Agricultural Societies. Malden, MA: Blackwell.

Bouckaert, Remco, Philippe Lemey, Michael Dunn, Simon J. Greenhill, Alexander V. Alekseyenko, Alexei J. Drummond, Russell D. Gray, Marc A. Suchard, and Quentin D. Atkinson 2012 Mapping the Origins and Expansion of the Indo-European Language Family. Science 337(6097):957-960.

Clark, Grahame

1966 The Invasion Hypothesis in British Archaeology. Antiquity 40(159):172-189.

Renfrew, Colin

1987 Archaeology and Language: The Puzzle of Indo-European Origins. London: Jonathan Cape.

\title{
Heritage Regimes and the State by Regina F. Bendix, Aditya Eggert, and Arnika Peselmann, eds.
}

\author{
Göttingen Studies in Cultural Property, 6. Göttingen: Universitätsverlag Göttingen, 2012. 413 pp.
}

\section{Noel B. Salazar}

University of Leuven

Heritage Regimes and the State is edited by German anthropologists who form part of an interdisciplinary research unit on cultural property at the University of Göttingen. The book is the result of two conferences (in Germany and Italy) that focused on the interface of international heritage regimes and their implementation at the state level. The key concept of "regime" is borrowed from international regulatory theory, referring to a set of rules and norms regulating the relations among actors on an international level. Applied to heritage, the regulatory framework includes UNESCO's World Heritage Convention and its Intangible Cultural Heritage Con- vention. To state the obvious, heritage making is never pursued simply for the sake of preserving and safeguarding. From a comparative global perspective, the volume answers the question of what happens in terms of translation and interpretation when the UNESCO conventions are ratified and implemented by a state.

While it is impossible to review the 17 case studies that provide evidence for divergent heritage regimes across the planet (with Europe being slightly overrepresented), it is worthwhile to discuss here the introductory reflections and concluding assessments. In the introduction, the editors focus on the following intertwined issues: the diversity of bureaucracy, political history, precursor value regimes, heritage strategies from the local to the international level, 
and the power of go-betweens and interpreters. Kristin Kuutma, both a heritage scholar and practitioner, warns for the pitfalls of mere deconstructionist scholarship. At the same time, she values the anthropological approach to heritage because it "advocates an investigation that utilizes different perspectives to contribute to our understanding of the social world by complicating simplicities" (p. 33).

The main part of the book is made up of three sections with case studies, respectively titled: "The Reach of (Post-) Colonial Sentiment and Control"; "Layers of Preservation Regimes and State Politics"; and "States and Their 'Thing': Selection Processes, Administrative Structures, and Expert Knowledge.” The latter is perhaps the most interesting because it offers detailed views of heritage nomination procedures, including the role of anthropologists as both expert consultants and researchers of the heritage-making process. In one of the contributions, Jean-Louis Tornatore interprets the application of the Intangible Heritage Convention in Western countries as a kind of "anthropological payback," forcing the objectification of the culture of those who used to objectify others in the past. At the same time, one could argue that the global expansion of heritage regimes constitutes a kind of objectification of the discipline of anthropology itself.

The closing commentaries are by Donald Brenneis, Rosemary Coombe, and Laurajane Smith. Coombe is the one that engages most with the role of anthropology in cultural heritage. She argues that "anthropologists need to move beyond an emphasis upon the reifying and objectifying nature of preserving cultural heritage to consider the ways in which the new international emphasis on safeguarding living traditions and ensuring the participation of communities creates new opportunities for political aspiration, articulation and assemblage" (p. 385). Chiara De Cesari closes the volume with a summarizing chapter. She identifies as main themes in the case studies: (1) imperfect translations; (2) heritage effects; and (3) the need for ethnography. De Cesari rightfully questions whether we should talk about "one heritage regime as a rather Eurocentric discourse" or, on the contrary, "multiple overlapping and intersecting heritage regimes, related to the different scales and the actors that nurture and champion them" (p. 403). Importantly, she points out that "UNESCO's cultural work is something anthropologists can no longer ignore, even if heritage is far away from their concerns" (p. 404). How, then, do we, as anthropologists, deal with "a certain bureaucratization of anthropology, with its knowledge turned into itemized lists and standard formats" (p. 404)?

In sum, this edited volume helps to broaden the idea that cultural heritage is "primarily a cultural construction that happens in the present and refers to the past" (p. 229). It serves as a thorough introduction into the complex world of UNESCO's heritage policies and its multiple translations on the ground. As added bonuses, the PDF version of the book is freely available online, and the volume "may serve as an encouragement to engage seriously ... with the ethnographic work and theorizing of non-Anglophone scholars in the field" (p. 20). Beyond the particularities of cultural heritage and the conflicting powers of heritage regimes, the volume disentangles how the global governance of a given policy construct "generates a bureaucratic apparatus with actors responsible for interpreting and applying procedures emanating from conventions and treaties" (p. 13). Perhaps most revelatory is this offering: "It is not simply human actors seeking or wielding power and holding control: the regimes themselves, as realized in unfolding bureaucratic institutions and processes, discipline both actors and their cultural practices into (perhaps) unforeseen dynamics" (p. 16). This book is thus not only recommended to scholars and graduate students in cultural anthropology or heritage studies but also to those with a broader interest in political anthropology, cultural policy, and governance "on the ground."

\section{Living with Oil: Promises, Peaks, and Declines on Mexico's Gulf Coast by Lisa Breglia.}

Peter T. Flawn Series in Natural Resource Management and Conservation. Austin: University of Texas Press, 2013.325 pp.

John Gledhill

University of Manchester

In his 2011 book Carbon Democracy, Timothy Mitchell argued that the switch to oil produced a radically new conception of "the economy" in which growth without limits became thinkable, but he notes that a few heterodox thinkers continued to worry about using up finite "natural" resources long before the Club of Rome-sponsored study The Limits to Growth, the "oil price shock" triggered by OPEC, and an increasingly strident environmentalist movement moved the issue back to center stage at the start of the 1970s (Mitchell
2011). In this more recently published work, author Lisa Breglia takes up the concept of "peak oil" developed by one of these figures, M. King Hubbert, to explore the implications of declining production in the principal source of Mexico's oil export bonanza, the Cantarell supergiant field located in shallow water in the Bay of Campeche. Peak oil in Mexico is also of interest for the United States. Mexico is that country's second most important oil supplier after Canada and shares a maritime border with its northern neighbor in the Gulf that has two "gaps" resulting from the limits of both countries' 200-mile Exclusive Economic Zones (EEZ). 